perhaps do some little service in drawing attention to the possibility of hidden sinus infection as a possible aetiological factor, but the authoress's criteria of its presence, and indications for treatment will hardly command universal approbation.

\title{
OBITUARY
}

\section{R. D. BEATSON HIRD, M.D., F.R.C.S. (Ed.) BE}

OPHTHALMOLOGY in the Midlands suffered a great loss by the sudden death on March 2, of Robert Dennis Beatson Hird, at the age of 67.

$\mathrm{He}$ received his medical education at Birmingham University, graduating M.B.,Ch.B., in 1905 and proceeding to M.D., a year later. He obtained the F.R.C.S. (Ed.) in 1909.

Practically the whole of his professional life spent in his native city of Birmingham, where much of his time was devoted to public work. Among the appointments which he held at various times were: Honorary Surgeon to the Birmingham and Midland Eye Hospital, Honorary Ophthalmic Surgeon to the General Hospitallater amalgamated with the Queen Elizabeth Hospital to form the Birmingham United Hospital, and Ophthalmic Specialist to the Birmingham Education Authority. During the war he served as Midland Regional Adviser in Ophthalmology to the Ministry of Health. He was Lecturer in Ophthalmology to the University of Birmingham until 1945.

Forty years ago he was one of the band of younger men who wrote abstracts for the Ophthalmic Review under the Editorship of E. E. Henderson, and he contributed original articles occasionally to its pages. $\mathrm{He}$ also. wrote papers in the medical journals and entered into discussions at the Annual Congresses of the Ophthalmological Society, but his literary output was not prolific and it was as a clinician that he was best known.

To all his work Beatson Hird brought those qualities which make for success. To abounding energy were added a deep knowledge and love of his speciality. He had an infinite capacity for taking pains and combined keen observation with attention to every detail. Nothing was too trivial to be noted and no effort too great which would enable an accurate diagnosis to be reached. These methods served as an example to many men now successfully practising ophthalmology in alt parts of the Empire. To him ophthalmology was not confined to narrow limits, but was only part of medicine as a whole. The posts he filled on the Stafts of large General Hospitals 


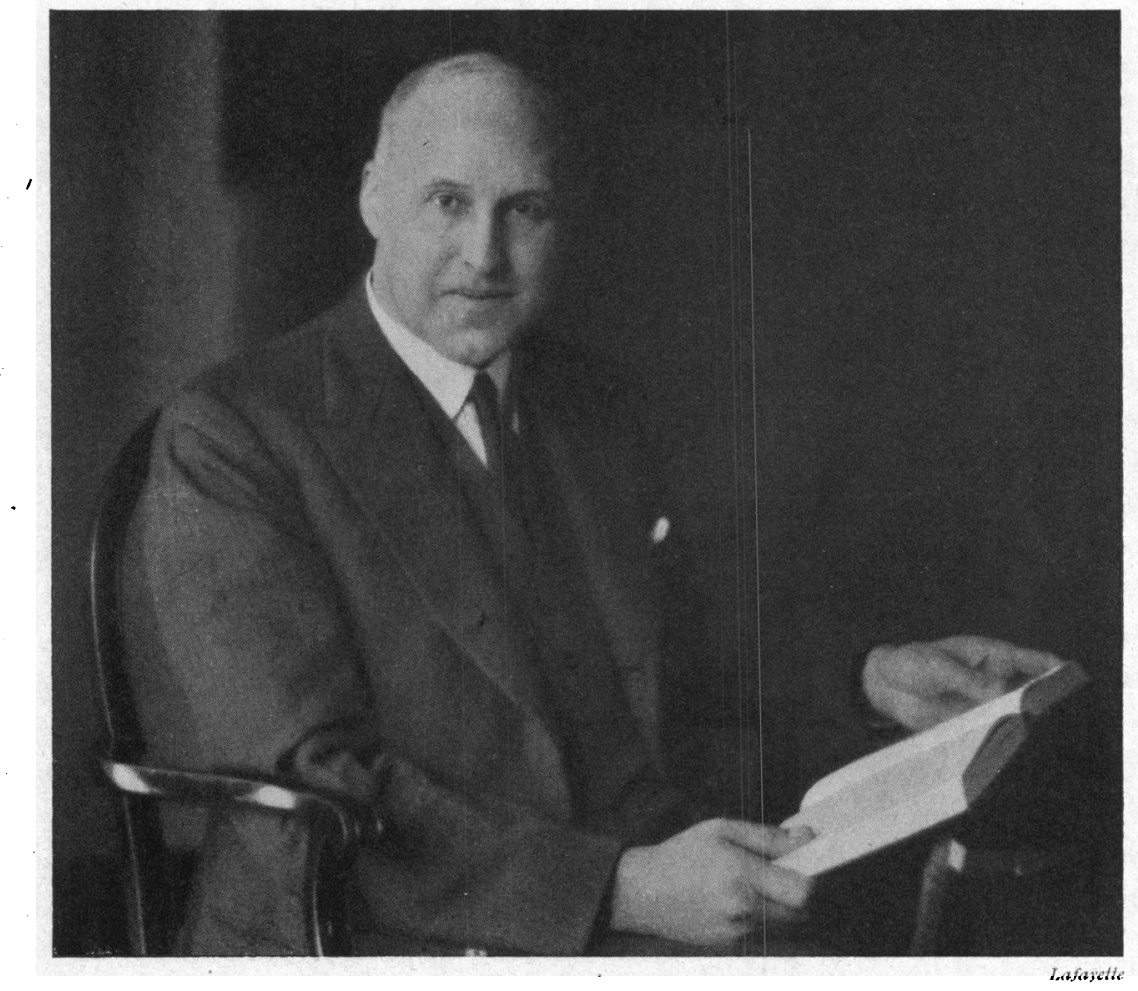

R. D. BEATSON HIRD 
enabled him to exercise to the full his skill in Medical Ophthalmology and his opinion, frequently sought by his colleagues engaged in the wider fields of General Medicine and Surgery, was often of the utmost assistance in difficult cases.

He was a successful teacher. Having an easy and lucid style he was able to leave a clear impression of his subject in the mind of the student.

Throughout the years his enthusiasm remained undiminished. $\mathrm{He}$ was ever ready to try new methods and to adopt those which he deemed in any way an improvement on the old.

His services as Midland Regional Adviser in Ophthalmology cannot be over-estimated and it was only his strong sense of duty in those difficult days which compelled him to continue such arduous work following a severe heart attack in the early days of the war.

Outside his profession he was a keen golfer until illness prevented strenuous exercise. He was also interested in astronomy, fond of literature and a discerning philatelist. His collection of rare stamps was amongst the finest and most valuable in the Midlands.

An outstanding personality, Beatson Hird was outspoken and direct, but these qualities were always combined with courtesy and an obvious sincerity. He will long be remembered with respect by friends and colleagues alike and their sympathy is extended to his widow and family.

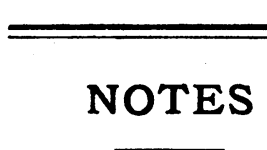

Deaths THE deaths are announced of Mr. Secker Walker, for many years of Leeds, and also of Lieut.-Col. Henry Smith, C.I.E., I.M.S., of Jullundur and Amritsar fame. Mr. Secker Walker was 82 and Lieut.-Col. Smith 91. We hope to publish notices of each in a later number.

Award THE Treacher Collins prize has been awarded by the Council of the Ophthalmological Society of the United Kingdom to Dr. H. S. Stannus, for his essay on nutritional eye disease.

University of Glasgow Department of Ophthalmology Spring, 1948 similar to the series held last year. Tea will* be served after the paper and a discussion will follow. The meetings 